\title{
Understanding Increased Violence in Early Post-Conflict Transitions and Its Implications for Development
}

\author{
Marcia Byrom Hartwell
}

February 2006

\begin{abstract}
A key issue for development in the late twentieth and early twenty-first centuries has been an escalation of violence during post-conflict transitions. A long-term goal for international donor involvement is to assist in building legitimate and effective political, economic, and legal institutions. However, research and observation has revealed that increased violence is commonplace during peace processes and strongly influences the ways in which these institutions are formed. In turn post-conflict violence itself is strongly influenced and motivated by the way in which peace agreements have been negotiated. This study addresses some of the reasons for escalation of violence following peace agreements. It describes the underlying dynamics including the relationship between perceptions of justice as fairness, formation of post-conflict identity, political processes of forgiveness and revenge; and the policy implications for development particularly in relation to peace conditionality tied to aid.
\end{abstract}

Keywords: conflict, peace agreements, institution building, development JEL classification: O1, O19, O21

Copyright (c) UNU-WIDER 2006

*Queen Elizabeth House, International Development Centre, Oxford.

This study is a revised version of the paper presented at the 17-18 June 2005 UNU-WIDER anniversary conference, 'WIDER Thinking Ahead: The Future of Development Economics', directed by George Mavrotas and Anthony Shorrocks.

UNU-WIDER gratefully acknowledges the financial contributions to the research programme by the governments of Denmark (Royal Ministry of Foreign Affairs), Finland (Ministry for Foreign Affairs), Norway (Royal Ministry of Foreign Affairs), Sweden (Swedish International Development Cooperation Agency_Sida) and the United Kingdom (Department for International Development). 
The World Institute for Development Economics Research (WIDER) was established by the United Nations University (UNU) as its first research and training centre and started work in Helsinki, Finland in 1985. The Institute undertakes applied research and policy analysis on structural changes affecting the developing and transitional economies, provides a forum for the advocacy of policies leading to robust, equitable and environmentally sustainable growth, and promotes capacity strengthening and training in the field of economic and social policy making. Work is carried out by staff researchers and visiting scholars in Helsinki and through networks of collaborating scholars and institutions around the world.

www.wider.unu.edu

publications@wider.unu.edu

UNU World Institute for Development Economics Research (UNU-WIDER)

Katajanokanlaituri 6 B, 00160 Helsinki, Finland

Camera-ready typescript prepared by Lorraine Telfer-Taivainen at UNU-WIDER

The views expressed in this publication are those of the author(s). Publication does not imply endorsement by the Institute or the United Nations University, nor by the programme/project sponsors, of any of the views expressed. 


\section{Introduction}

A key issue for development in the late twentieth and early twenty-first centuries has been an escalation of violence during post-conflict transitions. A long-term goal for international donor involvement is to assist in building legitimate and effective political, economic, and legal institutions, however, research and observation has revealed that increased violence is commonplace during peace processes and strongly influences the ways in which these institutions are formed. In turn post-conflict violence itself is strongly influenced and motivated by the way in which peace agreements have been negotiated. Peace processes in the late twentieth century have had a mixed record of success with the results from peace agreements often more divisive than unifying. Representation in the process may be skewed so that 'after a negotiated ending to a civil war, most countries lie in the intermediate terrain' between domestic forces who backed peace accord implementation, and 'hardliners on one or more sides who would prefer a return to armed conflict over implementation of the accords' (Boyce 2002: 32).

A lack of understanding by international interveners of the underlying dynamics within post-conflict societies has exacerbated many difficulties associated with developing this co-operation. Identifying and addressing these dynamics and their effect on internal and external motivations to pursue peace and create a stable environment for development has become increasingly important.

This study addresses some of the reasons for escalation of violence following peace agreements. It describes the underlying dynamics including the relationship between perceptions of justice as fairness, formation of post-conflict identity, political processes of forgiveness and revenge; and the policy implications for development particularly in relation to peace conditionality tied to aid. The fairness and humiliation issues cited elsewhere in this book by Mansoob Murshed are very relevant to this explanation. The conclusion observes that peace is an evolutionary process with some level of toleration between all groups as a goal that is necessary to prevent future conflict.

\section{Violence in peace}

Many of the problems central to recovering from conflict have focused on the process of political co-operation between former enemies. This co-operation is necessary to strike a peace agreement, to rebuild and create institutions, and to lay a foundation for sustainable peace. A little understood but increasingly menacing threat to peace processes is from rank and file members of irregular forces who do not support their leaders in making deals for peace. While non-state actors within each group have been fighting for the same cause, they may have had widely differing motivations. One of the biggest threats during post-conflict transitions is from 'spoilers', often leaders of irregular combatants, paramilitaries or other non-state groups who perceive that 
circumstances evolving from peace negotiations may not be in their best personal or political interests, and who use violence in attempts to undermine the process.

Halliday (2000: 286) has described four types of peace processes dominating post-Cold War conflicts throughout the 1990s that have been plagued by these types of underlying problems. One type is a process, which despite experiencing difficulties, makes progress that results in a stabilised, successful peace within a time frame of five to ten years. A second has been one where political negotiations continue but where unanticipated problems and delays have occurred. A third is where hostilities have formally ceased but where a political stalemate exists between all parties and the process becomes stalled; and a fourth is where peace breaks down completely and conflict is renewed at the previous or an escalated level of violence. These differences become clearer once a peace agreement has been struck. Stedman (1997: 7) has asserted that 'peace processes create spoilers'. During a conflict 'there are combatants, who can be identified in myriad ways-for example, rebels, bandits, pariahs, rogues, or terrorists' but 'spoilers exist only when there is a peace process to undermine'. Peace creates spoilers 'because it is rare in civil wars for all leaders and factions to see peace as beneficial. Even if all parties come to value peace, they rarely do so simultaneously, and they often strongly disagree over the terms of an acceptable peace'. As Keen (2001: 12, 18-19) noted 'the art of facilitating a transition from war to peace may lie, to a considerable extent, in ensuring that some of those benefiting from war are in a position to benefit to a greater extent from peace'.

This type of post agreement organizational fragmentation has been consistently observed in the ease with which upper echelons of paramilitary and rebel groups have appeared to gain political legitimacy in the early phases of a peace process while the bottom half or dissident members of the organizations have failed to find dramatic improvements in their living conditions. While elite leaders of these groups often gain legitimate political power through negotiation, non-elite members often feel that their socioeconomic and political needs have not been addressed in a final settlement.

Research demonstrates that preventing the lower echelons of the former rebel/paramilitary groups that have been marginalised by peace negotiations from shifting into organised crime requires a different kind of assurance and assistance than the paramilitary elite. Their perception of equal access to economic, political, and social opportunities are especially relevant to their willingness to co-operate in the early post conflict phase and directly impacts political co-operation and formation of institutions. The bottom half of the non-state organizations, often composed of those who have fallen out of favour with rebel or paramilitary leaders or who are among the many urban and rural poor who have survived in areas of constant battles, face the type of low paying employment available to those with their lack of qualifications, thus guaranteeing a future of grinding poverty. For them, disruptions to peace and alliances with organised crime networks are a guarantee of substantial income and elevated social status. 
As has been illustrated in post-agreement paramilitary punishment beatings and intimidation in Northern Ireland; transitional violence between African political parties in South Africa; political assassinations and organised crime in post-war Serbia, violence may shift rapidly from inter to intra group targets. This may result in an increased number of assassinations, punishment beatings, vigilantism, coercion, forced exile, and other forms of intimidation used to settle scores and jockeying for political power among one's own group.

As many non-state organizations have a youth recruitment and membership wing, this lack of hope for a better future has negative implications for long term development strategies that do not address this problem during post-conflict transitions. If these youth do not perceive that their chances of access to a better future or life have improved, then they are likely to evolve into or join criminal organizations and gangs (Dowdney 2005).

\subsection{Underlying dynamics in post-conflict transitions}

No action by aid donors or peacekeepers is without consequence in a post-conflict environment, with all forms of international development, aid, and peacekeeping missions under constant evaluation by internal populations. During fieldwork conducted in Northern Ireland, Serbia, and South Africa over a period of three years (Hartwell 2005), and in findings of others working with adult non-state actors and youth gangs (Dowdney 2005) it has become obvious that there are common dynamics and evaluation criteria shared by both post-conflict transitions and severely unstable environments. These underlying motivations have been most accurately depicted in a framework incorporating interactions between perceptions of justice, identity, and political processes of forgiveness and revenge. Perceptions of justice as fairness, where the perceived fairness of the process of arriving at a judgment has proven to be more important than the actual outcome; formation of a post-conflict identity where all groups share a common sense of victimization; and political processes of forgiveness and revenge that incorporate these motivations in enactment of or forbearance from a range of expressions of forgiveness and revenge are key influences on the process of building political co-operation and institutions (see Hartwell 2005).

Of these dynamics, perceptions of justice as fairness, also known as 'justice judgments', have been identified as a prime motivator and key to formation of identity and political processes of forgiveness and revenge. While not replacing formal legal trials and other procedures, these perceptions are formed early by all groups in order to rapidly assess their individual and group status in an unstable post-conflict transition and directly influence decisions and opinions affecting co-operation with former enemies (Hartwell 2004, 2005).

An assumption of a victim identity is common among all groups. While still focused on conflict-defined groupings, many civilians and non-state actors were less concerned with inter-group grievance than with groups' perceptions of themselves as victims of 
violence. In each case the formerly dominant group was especially vulnerable to assuming this identity and an articulation of victimhood has often found to have been a motivating factor for this group in initiating or prolonging the original conflict. The link between perceptions of justice and formation of post-conflict identities has been found to be of greater significance than had been previously understood. Individuals and groups were observed to renegotiate their identities utilising their perceptions of justice as fair treatment which in turn shaped political processes of forgiveness and revenge (Hartwell 2004; 2005).

In recent work on the relationship between justice, identity and behaviour, Tyler and Blader (2003: 353-4) observed that development and maintenance of a positive individual and group identity most strongly influences co-operation and leads 'people to be internally motivated to engage in and co-operate' with groups. Attitudes and values are an important part of this process as 'to the degree that people are internally motivated, they engage in co-operative behaviours for personal reasons, and they do not need to receive incentives (rewards) or to face the risk of sanctions (punishments) to encourage their group-related behaviours'. Tyler and Blader found that social identity is formed from three interconnected areas; identification, pride and respect:

Identification reflects the degree to which people cognitively merge their sense of self and their evaluations of self-worth with their judgments of the characteristics and status of their groups. Pride reflects the person's evaluation of the status of their group. Respect reflects their evaluation of their status within the group.

These perceptions of justice and formation of a victimization identity are linked to a complex parallel, evolutionary, and inevitably political process of forgiveness and revenge in a post-conflict transition. Although still in its infancy, the analysis of forgiveness and revenge and its relationship to political processes present in all national and international political systems raises important questions for the international community as well as the internal victims, perpetrators, and bystanders:

When considering how forgiveness unfolds for victims, the motivations underlying forgiveness decisions become important. Do people forgive to release themselves from discomfort, or do their decisions reflect more principled motives? Are such distinctions about motives important, in terms of predicting outcomes for forgivers or offenders? (Exline et al. 2003: 345)

In the past decade, inspired by the South African Truth and Reconciliation Commission (TRC), intangible issues such as forgiveness, previously treated as irrelevant political concepts by most non-theologian scholars and policy makers, began to be widely discussed in political and legal forums. Inclusion of forgiveness began to emerge in international peacemaking discussions as a new way forward in the process of promoting social reconciliation. However, examining the political dimensions of 
forgiveness and revenge was not new and had been previously discussed by postSecond World War philosopher Arendt (1958) who had explored the motivations of Nazi Germany, and later in the 1980s by Jacoby (1985) who examined the relationship between justice and revenge. However, it was not until the mid 1990s when studies such as Shriver (1995) appeared that a serious discussion outside of Christian theological paradigms began to take place.

Shriver, a pastor in North Carolina and participant in the 1960s civil rights marches in southern USA concluded that the concept of forgiveness which had been 'customarily relegated to the realms of religion and personal ethics' belonged 'at the heart of reflection' in pondering ways that groups of humans could repair damage from past conflicts with each other. Because forgiveness embraced 'moral truth, history, and the human benefits' that flowed from conquering enmity, Shriver (1995: x) defined 'forgiveness' as a 'word for a multidimensional process that is eminently political'.

Subsequent research and fieldwork has clearly underscored Shriver's interpretation and reinforced the work of Arendt and Jacoby. Both forgiveness and revenge have emerged as deeply intertwined parallel processes that directly impact political co-operation while encompassing all aspects of justice. This has been reflected in justice studies where considerable evidence has begun to mount that when confronted with serious emotional issues of justice and injustice in 'high impact situations', individuals will give precedent to re-establishing justice over a sense of personal financial gain.

'If the justice motivation and emotional arousal are sufficiently strong, the imperative to act may narrow the focus of attention and thought' resulting in a diminished response to self-interest. Individuals may be willing to give up 'considerable economic incentives to punish a harm-doer', working instead to help those they perceive to be innocent victims rather than working to increase their own profit. In some cases they may go so far as to 'derogate their own self-worth' determined to withstand potentially severe political, economic, and social costs as a consequence for their support. In this context justice assumes a counter-intuitive position as an independent and important source of motivation, overriding and separate from 'self-interested desires to maintain self-esteem and maximize profits’ (see Lerner 2003: 396).

This analytical framework set against a backdrop of unstable hypersensitivity characteristic of post-conflict transitions emphasises the relevance of the justice motive to understanding the motivation for much of the violent behaviour in the post-conflict context. Research has suggested that while unconditional forgiveness may not be necessary, or possible, in order for enemies to co-operate in the short term, a key finding has been that forbearance from revenge rather than unconditional forgiveness, directly impacts political, social, and economic relationships between former enemies. Seen as a mid phase between processes of forgiveness and revenge, this 'passive resentment', where a decision to forbear from enactment of revenge has been consciously taken, has 
emerged as a key factor for moving political co-operation and reforms forward (see Hartwell 2005).

\section{Policy implications for development}

In keeping with the advent of peacekeeping in post-Cold War years, a type of peace conditionality tied to donors' economic and political reform agendas has come to dominate post-conflict environments as a basic criteria for aid. In the early 1990s, a signed peace agreement was viewed as a type of investment and loan security, serving as de facto 'peace' conditionality for international financial institution (IFI) donors such as the World Bank, International Monetary Fund (IMF), and others who focused solely on goals of macroeconomic stability and economic reform. A more formal 'peace conditionality' began to evolve by the mid 1990s as the international community increasingly acknowledged that economic reform was not a neutral force and that its outcome was strongly influenced by political and social factors.

Focused on both short-term enforcement of peace agreements and long-term sustainability of peace, peace conditionality has been known by a variety of names: conflict management, peace building, conflict transformation, conflict resolution, conflict prevention, peace making, and reconciliation (Boyce 2002: 8-9). This conditionality has been organised and implemented by governments, humanitarian aid agencies; civil society organizations (CSOs) composed of a range of institutions that includes non-governmental organizations (NGOs), faith-based institutions, professional associations, trade unions, research institutes, think tanks; IFIs such as the World Bank, IMF, European Bank for Regional Development (EBRD), large regional banks; and government donor agencies such as USAID.

Performance criteria have specified explicit targets for cuts in military spending while simultaneously creating new democratic institutions, demobilizing ex-combatants, protecting the public, and increased spending for health, education, and reduction of poverty. Informal policy dialogue between aid donors and recipients has been encouraged in cases where the link between aid and conditionality has been left intentionally vague to accommodate fluctuating circumstances (see Boyce 2002: 8-9). While it has been consistently observed that peace conditionality can be a useful tool, it is not a 'magic bullet' nor does aid 'necessarily act like water on the embers of conflict' (Boyce 2004: 1032). Despite being well-meaning in most cases, it may nevertheless result in a mismatch of requirements to the reality of needs on the ground. For example, a universal and key concern expressed by all parties in previous case studies and one resonating throughout all early post-conflict transitions has been heightened anxiety regarding personal security. This climate of fear is well understood by former combatants and civilian populations especially as civil and 'ethno-national conflicts' have usually been fought in the same territory where combatants live and where civilians often assume roles as actors or as targeted bystanders (MacGinty 2001: 641-2). 
Aid in these unstable post-conflict transitions is ineffective unless it is framed in a way that is flexible and responsive to the changing situation on the ground. Otherwise there can be no guarantee of personal protection for any individual or group while travelling to work, to school, or conducting other daily activities.

Priorities and agendas of donors can be equally problematic and may be in direct conflict with perceptions of populations on the ground. Making invalid assumptions about situations, and/or imposing values and systems within an environment where this may provoke increased resistance may result in long term instability that is dangerous to all parties. Demands made as explicit or implicit conditions for aid, such as badly timed international calls for specific individuals to face international tribunals, and aid linked to the formation of truth and reconciliation commissions may adversely affect internal perceptions of justice and negatively impact the co-operation necessary in forming key institutions (Hartwell 2004). For international interveners attempting to stabilize the environment by defusing short-term violence and avoiding long-term renewal of conflict, accurately identifying spoilers who are slowing or sabotaging an agreement or peace process will help to develop effective strategies to thwart them.

Overall there are three general categories of spoilers common to peace processes; total, limited, and greedy. Total spoilers can be most difficult long term, as they often have fixed, inflexible goals and ideologies, are led by individuals who see the world in win/lose terms and may exhibit pathological tendencies that prevent the pragmatism necessary for compromise. Limited spoilers usually have several inflexible, specified goals accompanied by demands for protecting the security needs of their followers. Greedy spoilers are somewhere between the first two, only with more flexible demands that are tailored to the evolving circumstances.

Since the beginning of the 1990s the international community has pursued three major strategies to address spoiler-caused problems; inducement, socialization, and coercion. Inducement takes a positive approach to addressing spoiler grievances that include a range of strategies incorporating fear, security, fairness, demand for greater benefits, justice, and legitimization or acknowledgement of their position. Socialization relies on establishing a combination of material and intellectual norms while wielding a carrot and stick approach to a system of rewards or punishments. Normative standards can include a commitment to defined democratic standards and adherence to protecting human rights by instilling fair and appropriate standards of governance among the elites and educating citizens in democratic processes of holding elites accountable.

Coercion has ranged from the use or threat of punishment, coercive diplomacy incorporating threats and demands, the use of force, and the two most common strategies - the 'departing train' and/or 'withdrawal' strategies. The departing train strategy combines the premise that a spoiler's demands and strategies are inappropriate and illegitimate and that the peace process will continue with, or without the spoiler's 
co-operation. Withdrawal assumes that an international presence during the peace process is desired and attempts to punish the spoiler by threatening a withdrawal of international support and peacekeepers from the peace process. A problem with this approach is that it is indiscriminately applied, potentially hurting those who have complied and rewarding spoilers who oppose international involvement (Stedman 1997: 13-4).

The most effective use of strategies is considered to be the application of either force or the 'departing train' scenario on total spoilers who 'cannot be accommodated in a peace settlement; they must be defeated or so marginalized that they can do little damage'; or implementation of some form of inducement that can include in some cases, a policy of socialization and/or coercion on limited spoilers who 'can be accommodated by meeting ...non-negotiable demands' (Stedman 1997: 14-5).

Greedy spoilers require a long-term socialization strategy but in the short term can be a serious problem. A controversial but somewhat common strategy has been to grant amnesty for prisoners, incurring an almost universally negative reaction among groups of all sides in countries where it has been implemented, such as Northern Ireland and South Africa. However, it has been equally clear that without prisoner co-operation in supporting peace agreements, using amnesty as a condition of their release, peace would not have occurred (Hartwell 2004, 2005).

As violence in peace processes has been continually on the increase, it is suggested that the following tasks be urgently undertaken and results taken on board by the international community for better understanding of ways to implement effective development programmes in violent post-conflict environments.

\subsection{Formal monitoring of perceptions of recipient populations}

One way to undertake a survey of perceptions would be to use a form of impact assessment that gauges the effectiveness of specific aid projects on different classes, ethnicities and regions that are the most sensitive to the previous violent conflict. This would give direct insight into how aid programmes and peacekeeping interventions are perceived. This could include all groups and individuals by targeting well known and marginalised organizations and by sending emissaries with instructions to gather more information through informal networking channels. Such an all-inclusive national survey strategy has been implemented in South Africa by the Institute of Justice and Reconciliation in tracking sociopolitical trends for their SA Reconciliation Barometer. This data would be relatively easy to index and to quantify. 


\subsection{Better identification of groups at risk}

In my general observation, noted in fieldwork conducted in Northern Ireland, Serbia and South Africa, and in the work of others, groups with the potential to be highly valuable indicators of instability in post-conflict environments are:

- Groups that have undergone a traumatic loss of power, usually the formerly dominant populations who feel they have the least to gain from a peace process. They are usually the ones most affected by loss of previous privilege and can belong to any socioeconomic class.

- Marginal socioeconomic groups of all sides, especially the most poverty stricken, as they are highly reactive to change. They have often borne the brunt of the conflict and have much more in common with mirror groups on the opposite side of a conflict, than with members of middle and upper socioeconomic classes within their own groups.

- Volatile young males in formerly dominant populations. They are usually excombatants or members of a lower socioeconomic class who do not perceive any personal gains from peace and can often instigate and lead serious violence. This specifically emerged as a problem in Northern Ireland and South Africa.

- $\quad$ Pensioners and the older generation who have least to gain in future earnings and benefits from the peace, and who have lost savings and pensions during the conflict with no potential for recovery. They can become very bitter, and delay or reverse political transitions to democracy by voting to bring fundamentalist or nationalist parties to power. This was a particularly disillusioned group in Serbia as middle class members of this age group had experienced peak career and quality of life benefits from socialism. Subsequently they saw their life savings stolen from the country's state run banks, leaving them impoverished by the end of the Yugoslav war.

- $\quad$ Non-elite members of paramilitary and rebel groups from all sides of the conflict who do not have access to political power, education, good jobs, or legitimate ways of achieving greater financial success. For them a 'normal life' in peace has no advantage over continuing to engage in and expand their range of criminal activities. Their peacetime criminal activities have often expanded into lucrative non-war revenue areas and tap into formation and perpetuation of youth gangs and international criminal syndicates. This situation was noted in Northern Ireland, Serbia, and South Africa. 


\subsection{Better understanding of language used in the public sphere}

The coded use of language has been often underestimated and misunderstood by external interveners as an indicator to signal peaceful or violent intent. During conflict, social coding of language assumes hugely significant importance. Apparently neutral words and harmless questions such as: Where do you live? Where did/do you go to school? Who do you work for? can signal inclusion or exclusion, or in more serious situations, life-threatening danger.

While adversarial groups may technically speak the same language they often use common words to indicate different meanings. Decoding this language is extremely important for understanding perceptions of aid and military intervention on the ground.

\subsection{Improvement in communication between internal populations and donors}

Aid givers and peacekeepers often assume their intentions are clear to recipient groups. Transparency and honesty about what an international humanitarian organization and/or peacekeeping mission has to offer (including both advantages and limitations) are highly respected in post-war environments where warfare has been dependent on deception, manipulation, propaganda and misinformation. An organization that clearly states reasons for being in a place, what it has to offer, and what it can and cannot accomplish will avoid tragic misunderstandings.

There is a vital need to develop effective links with local organizations below government level and to speak with diverse representatives of local populations that include qualified local actors in the process of policy making and implementation. The scope of sources can easily be widened beyond the usual 'official' range by ringing or emailing a list of secondary sources - a range of CSOs not ordinarily consulted by large international donors, for example, and requesting a list of contacts.

\subsection{Improvement in deciphering transitional violence}

While endemic to the peace and reconciliation process, it is the choice of targets during this time that is vital to understanding intent. Through more realistic preparation, cooperation, and communication, peacekeepers and aid workers can more accurately assess risk to themselves and populations they serve for what appears to be an almost inevitable rise in violence during a post-conflict transitional period.

A review of historic patterns of violence in the area and within the recent conflict, such as the extent and pattern of police and/or military abuse, nature of violence targeted toward civilians, and extent of vigilantism will help give external interveners the perspective to interpret violence as it occurs. In assessing risks of violence toward internal populations and external interveners, those intervening in post-conflict environments should ask the following questions: Is it being caused by 'spoilers' to the peace process? Is it politically motivated? Is it being used to settle internal scores? What 
does the timing and location reveal? Is it occurring early during the transition or later in one 'trouble' spot? Has racial or hate crime increased? If increases in crime rates are becoming problematic, then where is this occurring? What are the regions? Is there a distinct difference in types and rates of crime in urban versus rural locations?

\section{Conclusion}

Recently there has been increased recognition by many international institutions and aid givers that while post-conflict transitions share common vulnerabilities they often need to address very different combinations of problems. These are shaped and influenced by a variety of factors that include characteristics of the preceding conflict and cultural norms. The interdependence of political, security, economic and social aid activities needs to be better acknowledged and international donors and interveners should support a more integrated and unified framework for planning political, security, humanitarian, economic and development activities at a country level.

In this analysis, reconciliation has been viewed as both a short and long term process. In the short term, it is seen as a pragmatic co-operation between former enemies in rebuilding political, economic, and social institutions; in the long term, it is a process which encompasses multiple generations. In striving for sustained peace in a society where violent conflict has created deep distrust there is a need for all sides to develop a style of personal and political toleration that a majority can accommodate and a minority can aspire to. This toleration of groups with different histories, cultures, and identities is pursued not for its own sake, but because many aspire to its value as justification for a 'peaceful coexistence and of the life and liberty that it serves'. This toleration of difference shifts the burden of social accountability onto those who would reject these values through acts of indiscriminate abuse such as forced removals, ethnic cleansing and other destructive deeds, to justify their actions (Walzer 1997: 2).

It is evident from the timeline of interviews and observations of others that internal reactions to important issues evolve over time. Initial elation over implementation of peace agreements almost invariably gives way to disillusionment as progress is perceived to be occurring less rapidly or not in the way originally anticipated. While an initial agreement or bargain may be struck in the short term, long term sustainability of peace requires the international community to develop aid and peacekeeping missions with more multi-levelled approaches than those currently in place (see Hartwell 2005).

Most importantly, Walzer depicts toleration as an ongoing negotiated arrangement whose goal is to strike a balance that provides a version of peaceful coexistence that is in itself 'an important and substantive moral principle'. While not necessarily a formula for harmony, it nevertheless legitimises previously repressed or 'invisible' groups, and allows them fair access to competition for available resources. It has been found that politically engaged citizens who have a 'growing sense of their own effectiveness' in 
civil society are its best insurance against racist or extremist political ideologies and commitments. (Walzer 1997: 6, 107)

Seeking a form of toleration that facilitates political co-operation and a will to sustain peace is a challenging but necessary achievement for societies emerging from conflict. The extent of courage and determination required by all sides to achieve this phase has been widely underestimated and misunderstood by the international community. A firm resolve is required to pursue peace by those who have had a past mired in conflict and poverty. It is even more difficult when they do not perceive access to and hope for a better future. If the international community would begin to broaden its net of those they consult when implementing development strategies, they could begin to take a bigger majority of the disenfranchised on board rather than leaving them to cause disruptions and make preparations to fight another day.

\section{References}

Arendt, H. (1958). The Human Condition, University of Chicago Press: Chicago.

Boyce, J.K. (2002). 'Investing in Peace: Aid and Conditionality after Civil Wars', Adelphi Papers 351, The International Institute for Strategic Studies (IISS): London.

Boyce, J.K. (2004). 'Aid Conditionality as a Tool for Peacebuilding: Opportunities and Constraints', Development and Change 33(5): 1025-48.

Cox, M., A. Guelke, and F. Stephen (eds) (2000). A Farewell to Arms? From Long War to Long Peace in Northern Ireland, Manchester University Press: Manchester.

Dowdney, L. (2005). Neither War nor Peace: International Comparisons of Children and Youth in Organised Armed Violence, COAV: Rio de Janeiro.

Exline, J.J., E.L. Jr. Worthington, P. Hill, and M.E. McCullough (2003). 'Forgiveness and Justice: A Research Agenda for Social and Personality Psychology’, Personality and Social Psychology Review 7(4): 337-48.

Halliday, F. (2000) quoted by Cox et al.

Hartwell, M. (2004). 'The Concept of Justice in the Early Post-Conflict Period: a Comparative Perspective', in A. Guelke (ed.) Democracy and Ethnic Conflict: Advancing Peace in Deeply Divided Societies, published results of a colloquium of Research Committee (Politics and Ethnicity) of International Political Science Association, Belfast, 25-28 July 2001, Palgrave Macmillan: Basingstoke.

Hartwell, M. (2005). 'Perceptions of Justice, Identity and Political Processes of Forgiveness and Revenge in Early Post-Conflict Transitions, Case Studies: Northern Ireland, Serbia, South Africa', Ph.D thesis, Oxford University.

Jacoby, S. (1985). Wild Justice: The Evolution of Revenge, Collins and Bartholomew: Glasgow. 
Keen, D. (2001). 'War and Peace: What's the Difference?', in A. Adebajo and C.L. Sriram (eds) Managing Armed Conflicts in the $21^{\text {st }}$ Century, International Peace Academy, Frank Cass: Oxon.

Lerner, M.J. (2003). 'The Justice Motive: Where Social Psychologists Found It, How They Lost It, and Why They May Not Find It Again', Personality and Social Psychology Review 7(4): 388-99.

MacGinty, R. (2001). 'Ethno-National Conflict and Hate Crime', The American Behavioral Scientist 45(4): 639-53.

Shriver, D. (1995). An Ethic For Enemies, Forgiveness in Politics, Oxford University Press: Oxford.

Stedman, S.J. (1997). 'Spoiler Problems in Peace Processes', International Security 22(2): 5-53.

Tyler, T.R., and S. Blader (2003). 'The Group Engagement Model: Procedural Justice, Social Identity, and Co-operative Behavior', Personality and Social Psychology Review 7(4): 349-61.

Walzer, M. (1997). On Toleration, Yale University Press: New Haven CT. 